\section{Reprieve by default for academics}

\section{Washington}

IMMIGRATION legislation that could restrict university recruitment seemed to be foundering last week in a storm of racial sentiment and pre-election politicking. The controversial Simpson-Mazzoli bill is proving to be a sound stick with which newlyenthused Democrats in Congress can beat the Reagan Administration. The possible effects on scientific manpower in the United States seem to be largely overlooked.

While national attention focuses on the bill's provisions to apply an amnesty to illegal immigrants, universities seem to have resigned themselves to a back seat. The bill originally required foreign nationals studying in the United States to return to their home countries for a period of two years after graduating, before being allowed back into the United States. Not surprisingly, many of those who recruit graduates - both inside and outside the universities - were dismayed, and both houses of Congress accepted that this blunt instrument had to be sharpened.

In its present form the bill will allow exemptions to the "two years nonresidency" requirement, but the Senate and House of Representatives versions still differ. Educational lobbyists seem to have had their energies drained by their earlier efforts, and say they cannot expect to have any more influence on the bill. The exemptions will apply only to those who have been offered employment in the United States in the same field as their degree; others will be denied visa extensions. If the employment offered is on a faculty, the subject restrictions are waived; otherwise exemptions to the two years' foreign residency requirement are to be limited to those with degrees in natural science, mathematics, computer science or engineering.

The position of the American Council on Education, an umbrella body for various groups, is that the status quo should be preserved, with no new restrictions on recruitment. The bill will, if passed, at the very least make extra work for university administrators and could yet hinder recruitment. One of the difficulties admitted by the council is the lack of data on foreign nationals qualifying and working in the United States, although according to one survey conducted by the National Academy of Sciences something like 55 per cent of foreign nationals who obtain a PhD in the United States remain for long enough to seek a visa extension. But there is nothing like a complete profile of foreign students' employment, which is in itself hindering efforts by those representing the interests of universities and high-tech industry.

Engineering groups have been particularly concerned about the bill in the

past, but, like the universities, now seem resigned to whatever Congress hands down. The issue of labour certification the need to demonstrate that no US citizen can undertake a job awarded to a foreign national - is one area where the new bill could overturn the conventions that have been established. In particular, it is now to be questioned whether the outcome of an academic search will automatically satisfy the Department of Labor that a work visa is justified.

\section{UK fast breeder}

THE lack of major specific targets in the United Kingdom's development programme for commercial fast-breeder reactors has led to weakened financial control, according to a recent report of the influential House of Commons Public Accounts Committee*. The report urges that the Department of Energy and the UK Atomic Energy Authority (UKAEA) should be attempting to specify intermediate milestones - in terms of both achievement and cost - to enable the success of the programme and its cost effectiveness to be more easily assessed.

Following the government's decision to slow down fast-breeder development in 1982, UKAEA is cutting its annual expenditure on the project by a third to about $£ 70$ million a year. According to the authority's chairman, Sir Peter Hirsch, this is the minimum commensurate with effective participation in the European collaboration on fast breeder design (see Nature 307,$200 ; 1984)$. In his evidence to the committee, he reported that the total cost of a development programme leading

\section{Washington}

COMPUTER manufacturers in the United States seem on balance to be relieved by the new agreement on computer export controls reached last month by $\mathrm{COCOM}$, the international co-ordinating committee on strategic exports. The new rules will put US and European manufacturers on a more equal footing. But while some control limits were raised, new restrictions were imposed for small personal computers and software.

The agreement is seen as a major breakthrough in the vexed international issue of export controls: US attempts to enforce extraterritorial provisions in its own export control laws have been a continuing source of friction. The 15 member nations of COCOM (members of the North Atlantic Treaty Organization, minus Spain and Iceland, plus Japan) have been discussing the

\section{Accountants' worries}

The House of Representatives passed its own version of the bill by the narrowest of margins a few weeks ago, but is unlikely to allow any further concessions to the stricter Senate version. Senator Alan Simpson is still insisting that the bill will survive, although hopes of appointing a conference committee to seek a truce with the House before the forthcoming Republican convention have now been abandoned, apparently to spare the bill's supporters embarrassing political pressure. Others are by now convinced that the bill will be a hostage to the presidential election and will soon disappear without trace.
Tim Beardsley

\section{COCOM agreement on computers}

to commercial power stations was estimated to be $£ 3,100-£ 3,700$ million, depending on assumptions about future interest rates. This calculation assumes that a Commercial Demonstration Fast Breeder Reactor (CDFR) is constructed in 1993 and that power stations come on-line in 2005.

The Public Accounts Committee acknowledges the uncertainties in such calculations but notes that this is the first time that such a figure has been presented to Parliament. And because there is no government commitment to the construction of a CDFR, UKAEA's expenditure is set at an annual rate that cannot be judged by a specific timetable of development. Nevertheless, the committee urges that intermediate targets should, where possible, be agreed upon with the Department of Energy and costed accordingly.

Philip Campbell

*Thirty-second Report from the Committee of Public Accounts, Session 1983-84, Development of Nuclear Power (House of Commons Paper 367, HMSO, £4.15).
The maximum "processing data rate" of exported mainframe computers has been increased from 32 million bits per second to 48 million bits per second. For personal computers, the cut-off point will be between 7 and 8 million bits per second: the United States had been particularly keen to see controls on the smaller machines, which can have battlefield applications.

The new software controls will, it is believed, apply only to sophisticated realtime functions and will not cover standard programs. Telecommunications and switching equipment are also covered. But, despite the relief that agreement has been reached, there is still some frustration among the manufacturers that the details are to remain confidential, although some guidelines will probably be published.

Tim Beardsley 